ISSN: 0210-1696

DOI: https://doi.org/10.14201/scero2021523101117

\title{
THE USE OF VIDEOGAMES AS DIGITAL LEISURE AMONG PEOPLE WITH AUTISM SPECTRUM DISORDER
}

\section{El uso de los videojuegos como ocio digital en personas con trastorno del espectro del autismo}

José Luis Cuesta Gómez

Universidad de Burgos

Sergio SÁnChez Fuentes

Universidad Autónoma de Madrid

sergio.sanchezfuentes@uam.es

Santiago SANTOS VÁzQUEZ

Asociación Autismo Vigo

Patricia SAncho ReQuena

Universidad de Valencia

Martha Lucía Orozco Gómez

Universidad de Burgos

Recepción: 23 de enero de 2020

Aceptación: 13 de enero de 2021

AвSTRACT: Digital leisure and specifically videogames are increasingly entrenched in all segments of society. Making appropriate use of them implies a challenge for users, families, and professionals. In the present study, the use that people with Autism Spectrum Disorders make of this sort of entertainment is specifically approached, and a series of recommendations are presented that take the characteristics of this population into account. A questionnaire was prepared ad hoc for data-collection purposes and administered to 67 people with ASD of different ages. The results reflect that videogames are a very popular type of game among people with ASD, are perceived as highly attractive and motivating and can help to lower anxiety levels. Among the undesired aspects, the physical problems arising from the use of videogames may be highlighted, 


\section{THE USE OF VIDEOGAMES AS DIGITAL LEISURE AMONG PEOPLE WITH AUTISM SPECTRUM DISORDER \\ J. L. CUESTA, S. SÁNCHEZ, S. SANTOS, P. SANCHO Y M. L. OROZCO}

and the problems of addiction and isolation that their continual use can provoke. The widespread acceptance of this type of leisure among people with ASD calls for new studies of a qualitative nature for the analysis of the relevant variables.

KEYwORDS: ASD; digital leisure; video-game technology.

RESUMEN: El ocio digital, y en concreto los videojuegos, están cada vez más afianzados en todos los segmentos de la sociedad. Hacer un uso adecuado de ellos implica un desafío para los usuarios, familias y profesionales. En el presente estudio se aborda de manera específica el uso que las personas con Trastornos del Espectro Autista hacen de este tipo de entretenimiento y se presentan una serie de recomendaciones que toman en cuenta las características de esta población. Para ello, se elaboró un cuestionario ad hoc y se administró a 67 personas con TEA de diferentes edades. Los resultados reflejan que los videojuegos son un tipo de juego muy popular entre las personas con TEA, se perciben como muy atractivos y motivadores y pueden ayudar a reducir los niveles de ansiedad. Entre los aspectos no deseados, se pueden destacar los problemas físicos derivados del uso de videojuegos y los problemas de adicción y aislamiento que puede provocar su uso continuado. La amplia aceptación de este tipo de ocio entre las personas con TEA exige nuevos estudios de carácter cualitativo para el análisis de las variables relevantes.

Palabras clave: Trastornos del Espectro del Autismo; ocio digital; videojuegos.

\section{Introduction}

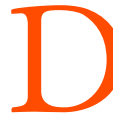

IGITAL LEISURE, UNDERSTOOD AS LEISURE that involves a level of interaction with one or more technological devices (computers, consoles, smartphones, etc.), is widely integrated within all social segments of our society. Their increasingly frequent usage is behind many studies, which have analyzed the use of Information and Communication Technologies (ICT) for the enjoyment of digital leisure time. More specifically, the work completed by Spracklen (2015) and the study described by Ang et al. (2018) show their possible benefits and associated problems, as well as their impact on the general population.

Many people with Autism Spectrum Disorder (ASD) with good cognitive functions find these technologies very attractive, given than many of their characteristics are especially well adapted to the characteristics of people with ASD, with respect to the processing of information, learning styles, information channels, little or no need for social skills, etc. (Blythe et al., 2018). However, attention has hardly been given to that population group and the use that they make of this type of leisure activity (Chan et al., 2013). It is a reality that contrasts with the real use that people with ASD make of digital leisure, because it is an option that many children, adolescents and adults with ASD choose as a means of highly gratifying entertainment (Finke et al., 2018).

In the field of digital leisure, one of the most widely used options are videogames, set up as interactive applications, principally for entertainment purposes which, using remote controls, can simulate on-screen experiences of an electronic device. These 
videogames, as Kientz et al. (2013) and Shic and Goodwin (2015) affirmed, are invariably not especially designed for people with ASD, unless of a specific type that is generally, more educative than leisure-related nature.

It also has to be considered that digital leisure, as with the general population, can entail both pros and cons for the population with ASD. According to Baldassarri et al. (2020), technology and videogames are instruments that motivate people with ASD to practice attention, planning, and complex communications skills. Nieto et al. (2015) pointed out that the communicative and social difficulties of people with autism often limit their leisure opportunities and contribute to enjoyment through technology. It can be used for individual activities that are close up, which is a center of interest shared by many people with autism. The study conducted by Yaghoubi et al. (2019) pointed to the risk of addiction to videogames and the possible appearance of behavioral problems associated with the excessive lengths of time that the person spends playing. It must be taken into account that some characteristics associated with this disability, such as inflexibility and the tendency towards routine, can imply obstacles when playing with these sorts of programs (Mazurek et al., 2015).

Orozco et al. (2017) added weight to the idea that technological tools must be designed to favor inclusion, taking into account the diversity of the potential users and their different qualities and characteristics. People with ASD are characterized by their great heterogeneity with regard to the clinical manifestations of their symptoms (Grzadzinski et al., 2013), maintaining some common characteristics with regard to difficulties in social relations, communication, restricted interests, and repetitive or stereotyped behaviors (APA, 2013). In addition, the presence or otherwise of intellectual disability, speech disorders, motor problems, emotional problems, and lengthy et cetera, imply that each individual diagnosed with ASD is unique (Frith, 1989; Happé, 2011). As Tsikinas and Xinogalos (2019) affirmed, for this reason, computer games that fit the cognitive and adaptative profiles of each person with autism are difficult to find.

As Fletcher-Watson (2015) affirmed, there are numerous studies on the implications of the use of ICTs among people with ASD, however most of them are centered on the use of ICT tools to improve both the teaching and the learning processes of students with ASD (Acedo et al., 2016; Cintado et al., 2016; Espino, 2010; Lozano et al., 2011; Martínez et al., 2016; Travers et al., 2018). The technologies related with videogames, among other aspects, also imply a source of entertainment that is usually quite popular among people with ASD, on which there is little investigation (Mazureck and Wenstup, 2013). In view of the above, the principal objective of this study is therefore to understand the views of people with autism towards the use of videogames, in relation to the frequency with which they are played, the type of platform that is used, the justification for their use, the social reasons, the advantages and the disadvantages that they perceive, the types of game preferred, and the evaluation of the game as a leisure activity. 


\section{Method}

\subsection{Participants}

A total of 67 people diagnosed with ASD participated in the study, nevertheless, not all of them formed part of the final sample. Given the objective of the investigation, only those participants were selected who stated a liking for videogames, so that the final sample comprised 54 people, mainly men $(94.4 \%)$, with an average age of 16.01 years old $(\mathrm{DT}=5.35$; $\mathrm{Min}=6$; $\mathrm{Max}=33)$. The participants were selected through previous contact with specialized autism-related agencies, which were asked to identify individuals that met the following requirements: (1) to have been diagnosed with ASD; (2) to have a sufficient grasp of the meaning of the questions; (3) to be capable of answering in an independent manner; and, (4) to have voluntarily decided to participate in the study. As it was an exploratory study, proposed as an initial exploration of the reality, inclusion of the maximum number of participants was considered, without establishing any specific age-related criteria.

\subsection{Instrument}

An ad hoc questionnaire with 21 questions was administered that covered multiple-choice questions, scaled responses, and open questions. Both the earlier study of Mazurek et al. (2015), called Video games from the perspective of adults with autism spectrum disorder, and the publication of the Spanish Association of Entertainment Software Distributors and Editors, El videojugador español: perfil, hábitos e inquietudes de nuestros gamers (2011), were taken into account for the preparation of the questionnaire. The questionnaire included items referring to the degree of interest in videogames, their frequency of use, devices that are used, time dedicated to playing, reasons why they like them or not, who they play with, and the advantages and the inconveniences that refer to them.

\subsection{Procedure}

The questionnaire was prepared with Google online technology. Having completed the design, the questionnaire was sent by e-mail to different associations and professionals related with people with ASD in Spain, so that they could send it to people with ASD of all ages who might be interested in participating in the study. The questionnaire was answered in full and all the information was anonymously gathered, in compliance with ethical and confidentiality principles.

\subsection{Data analysis}

In addition to descriptive statistics (frequencies, averages, and standard deviations), different analyses were performed, taking into account the nature of the varia- 
bles involved in the study: Chi-squared, ANOVAs, MANOVAs and Pearson correlations. The Pearson correlations were interpreted in accordance with Cohen (1988), as either small $(r=.10)$, moderate $(r=.30)$, or high $(r \geq .50)$. All the analyses were performed with the SPSS 21 software package.

Taking the objective of the investigation as a reference, the results are presented as follows.

\subsubsection{The frequency of use of the videogames}

People with ASD showed that the frequency of video game use ranges from every day $(58.5 \%)$ and 1 or 2 times a week $(39.8 \%)$, with a very low percentage of people who only played 1 or 2 times a month (1.9\%). In addition, a typical session was over 2 hours $(44 \%)$ or 4 hours $(31.5 \%)$ in the majority of cases, followed by a frequency higher than 3 hours $(14.8 \%)$ and 1 hour $(9.3 \%)$.

\subsubsection{Game platform}

Having initially administered the surveys, the types of platforms that people with ASD typically use were identified, with a greater preference $(63 \%)$, for the computer and the console.

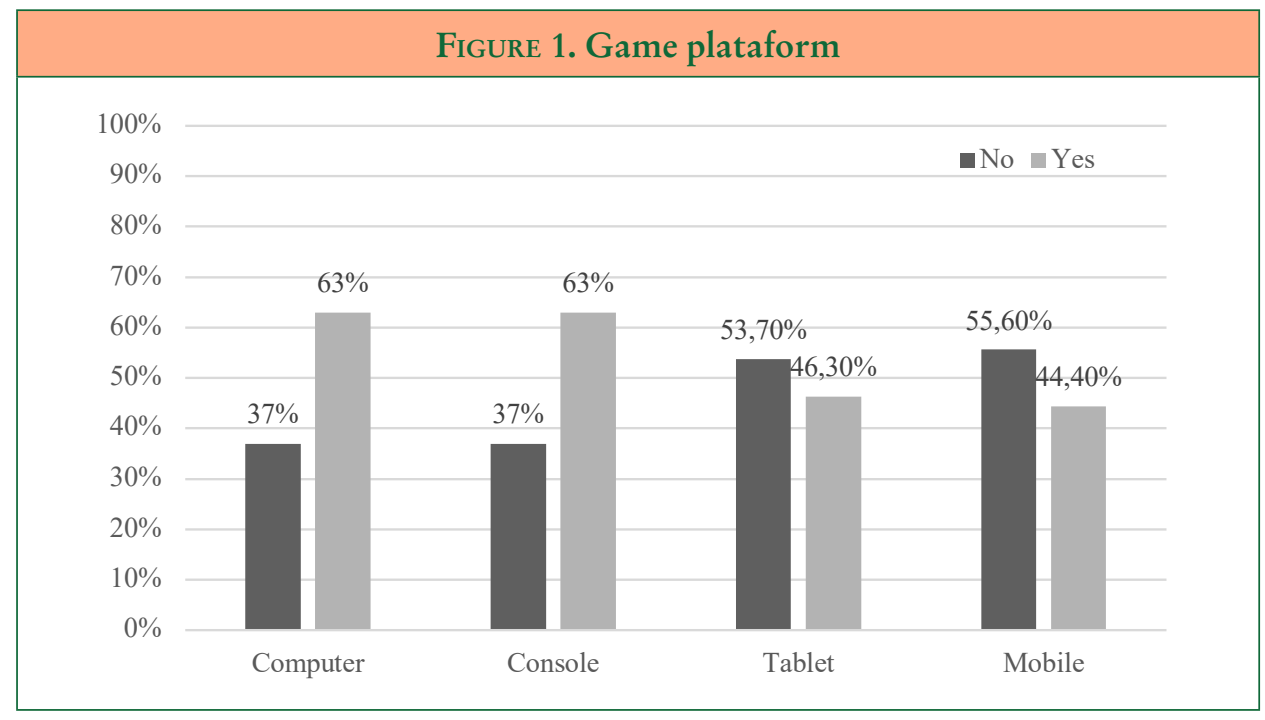


2.4.3. Reasons for either playing or not playing

The results showed that the most frequently mentioned reason among the participants for choosing this type of entertainment was enjoyment (Figure 2).

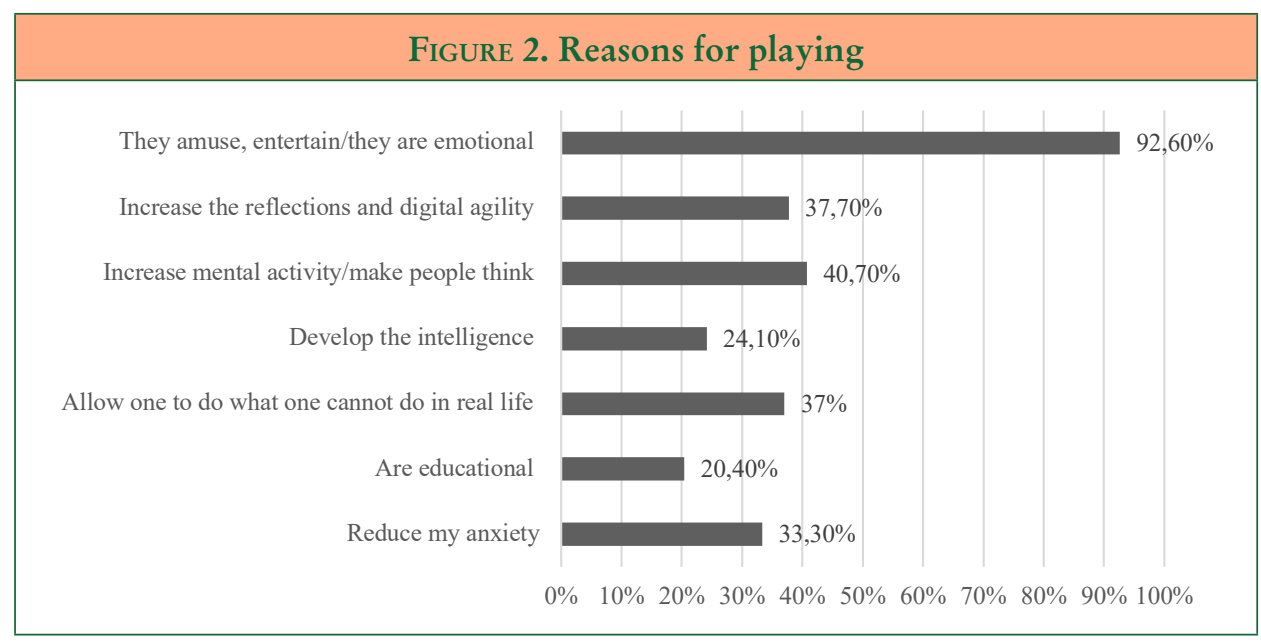

The results of the study on reasons, by age, showed only one effect when the reason was to increase mental activity and/or to perform impossible activities (Table 1). In both cases, it was a reason that players of over 18 years old mentioned more frequently.

\begin{tabular}{|l|c|c|c|}
\hline \multicolumn{4}{|c|}{ Table 1. Chi-squared between Age and Reason for Playing } \\
\hline \multicolumn{1}{|c|}{ Dependent variable } & $X^{2}$ & $g l$ & $p$ \\
\hline Entertainment & 1.651 & 2 & .438 \\
\hline Reflexes & 3.162 & 2 & .206 \\
\hline Mental activity & 6.426 & 2 & .040 \\
\hline Intelligence & 3.054 & 2 & .217 \\
\hline Fantasy & 6.070 & 2 & .048 \\
\hline Education & 1.161 & 2 & .560 \\
\hline Anxiety & .122 & 2 & .941 \\
\hline
\end{tabular}


THE USE OF VIDEOGAMES AS DIGITAL LEISURE AMONG PEOPLE

WITH AUTISM SPECTRUM DISORDER

J. L. CUESTA, S. SÁNCHEZ, S. SANTOS, P. SANCHO Y M. L. OROZCO

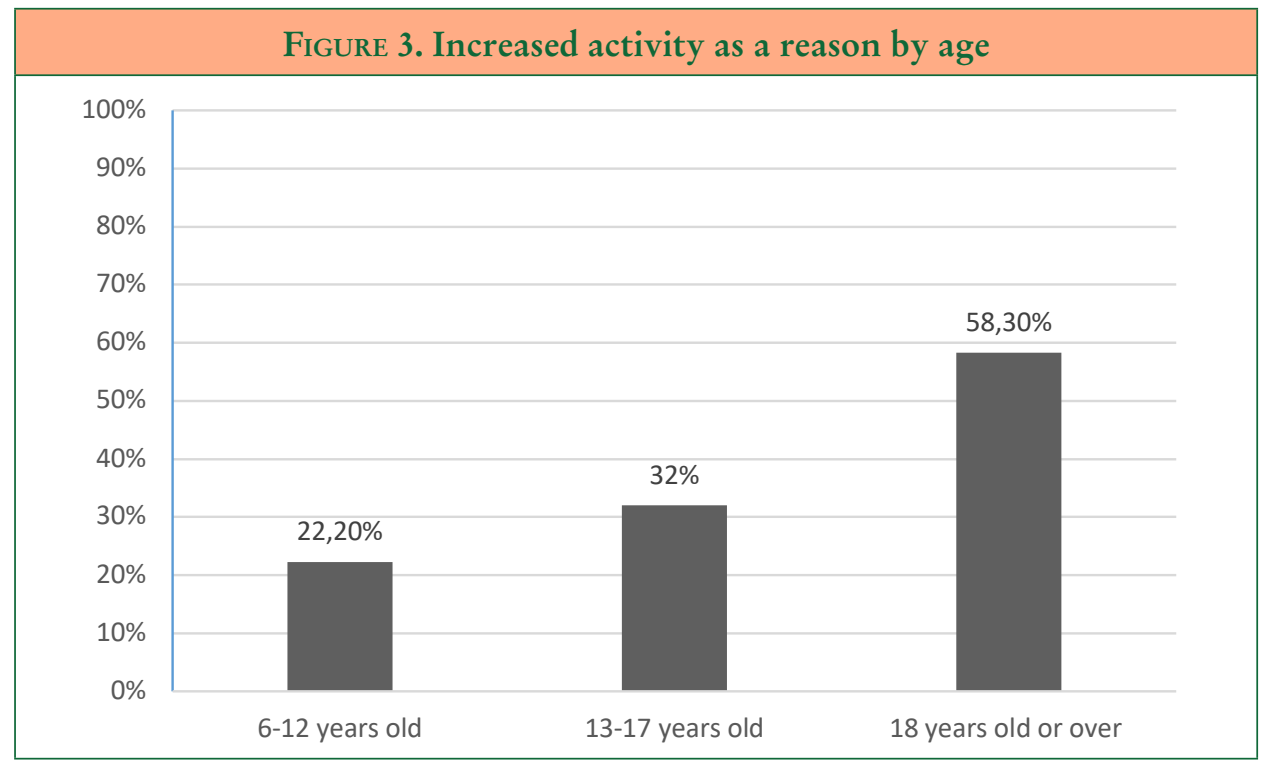

Figure 4. Perform impossible activities as a reason by age

$100 \%$

$90 \%$

$80 \%$

$70 \%$

$60 \%$

$50 \%$

$40 \%$

$30 \%$

$20 \%$

$10 \%$

$11,10 \%$

$0 \%$

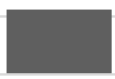

$6-12$ years old

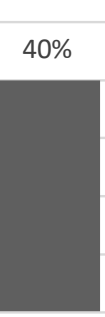

$45,80 \%$

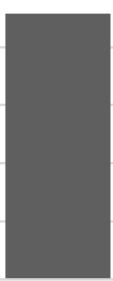

13-17 years old

18 years old or over

Ediciones Universidad de Salamanca / CC BY-NC-ND

Siglo Cero, vol. 52 (3), 2021, julio-septiembre, pp. 101-117

$$
-107 \text { - }
$$


On the contrary, the reasons for not playing were lack of time and choice of another sort of leisure activity, on the majority of occasions $(27.3 \%)$, followed by boredom, lack of skill, and having other responsibilities (9.1\%), and its high cost, its damage to health or that their parents would not allow it, in the fewest cases $(6.1 \%)$. The results showed that there were no significant gender differences in relation to the above reasons $\left(X^{2} 7=7.404, p=.388\right)$.

\subsubsection{Social reasons}

The most common way of playing was to play alone $(69.2 \%)$, followed by playing together with family or friends $(18.5 \%)$ and online $(12.3 \%)$. In this last case, there was no statistically significant effect by age $\left(F_{2,62}=.157, p=.855\right)$. These percentages coincided with the preferences for playing in company: only $=55.6 \%$, accompanied $=25.4 \%$, online $=14.3$ and indifferent $=4.2 \%$. In this case, were there no differences by age $\left(X^{2}{ }_{3}=3.122, p=.373\right)$.

\subsubsection{Advantages and disadvantages}

As may be seen in Table 2, those surveyed considered that the main disadvantages found with playing were the possibility of obsession or addiction and the time that the players dedicated to this activity, which reduced the time available for study and other tasks. Besides, the results showed higher averages in the case of advantages, highlighting increased intelligence and the avoidance of problems.

\begin{tabular}{|c|c|c|c|c|c|}
\hline & & Minimum & Maximum & Average & SDev \\
\hline \multirow{5}{*}{ Disadvantages } & Obsessive or addictive & 1.0 & 5.0 & 3.761 & 1.102 \\
\hline & Loss of time & 1.0 & 5.0 & 3.507 & 1.146 \\
\hline & Causes physical strains & 1.0 & 5.0 & 2.866 & 1.324 \\
\hline & Causes social isolation & 1.0 & 5.0 & 3.288 & 1.356 \\
\hline & $\begin{array}{l}\text { Causes violence between } \\
\text { players }\end{array}$ & 1.0 & 5.0 & 2.985 & 1.331 \\
\hline \multirow{3}{*}{ Advantages } & $\begin{array}{l}\text { Increases intelligence and } \\
\text { reflexes }\end{array}$ & 1.0 & 5.0 & 3.627 & 1.152 \\
\hline & $\begin{array}{l}\text { Helps to know friends and } \\
\text { people }\end{array}$ & 1.0 & 5.0 & 3.138 & 1.367 \\
\hline & $\begin{array}{l}\text { Helps to relax and forget } \\
\text { problems }\end{array}$ & 1.0 & 5.0 & 3.687 & 1.339 \\
\hline
\end{tabular}


Two MANOVAs were calculated to study the effect of age both on advantages and disadvantage. No statistically significant differences were found with regard to advantages for the linear combination of the variables under study $\left(F_{10,120}=.437, p=\right.$ .853). Likewise, with regard to the disadvantages, no statistically significant differences were found for the linear combination of the variables under study $\left(F_{10,118}=1.401\right.$, $p=.188)$.

\subsubsection{Type of game}

As may be seen in Figure 5, the types of game preferred by the survey participants were action and strategy games. The results showed statistically significant differences by age in the case of the choice of gaming platforms (Table 3), a type of game chosen above all by the youngest players in the sample $(6-12$ years old $=44.4 \%$; 13 17 years old $=13 \%$; older than 18 years old $=12.5 \%$ ).

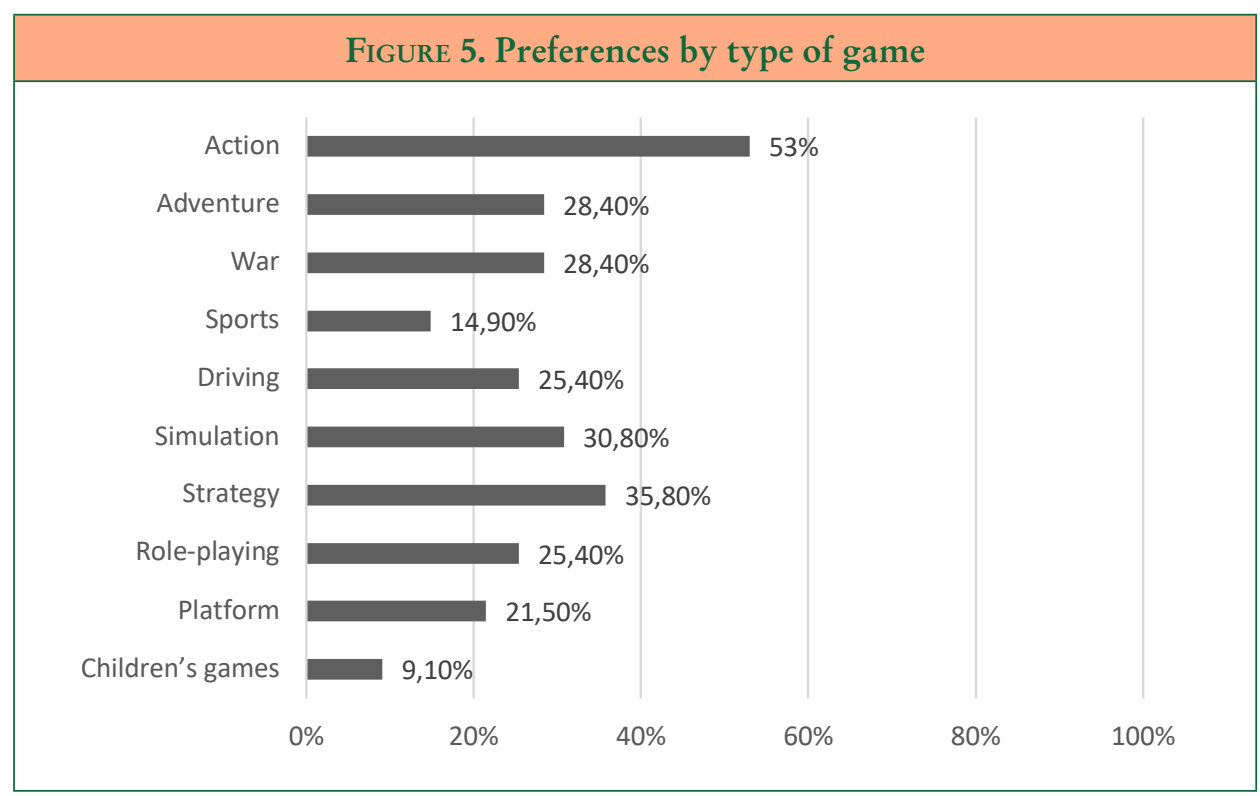

Ediciones Universidad de Salamanca / CC BY-NC-ND

Siglo Cero, vol. 52 (3), 2021, julio-septiembre, pp. 101-117 
THE USE OF VIDEOGAMES AS DIGITAL LEISURE AMONG PEOPLE

WITH AUTISM SPECTRUM DISORDER

J. L. CUESTA, S. SÁNCHEZ, S. SANTOS, P. SANCHO Y M. L. OROZCO

TABle 3. Chi-squared between Age and Type of Game

\begin{tabular}{|l|c|c|c|}
\hline \multicolumn{1}{|c|}{ Dependent variable } & $X^{2}$ & $g l$ & $p$ \\
\hline Action & 2.521 & 4 & .641 \\
\hline Adventures & .012 & 2 & .994 \\
\hline War & 1.185 & 2 & .553 \\
\hline Sport & .177 & 2 & .915 \\
\hline Driving & .407 & 2 & .816 \\
\hline Simulation & .278 & 2 & .870 \\
\hline Strategy & 5.627 & 2 & .060 \\
\hline Role-playing & 5.680 & 2 & .058 \\
\hline Platforms & 7.731 & 2 & .021 \\
\hline Children's games & 4.638 & 2 & .098 \\
\hline
\end{tabular}

\subsubsection{Evaluation of the game as a leisure activity}

A general evaluation of the game as a leisure activity was obtained with only one indicator (from 0 to 10 ), where an average of $7.864(S D=2.48$ ) was obtained for the sample. No statistically significant differences were found when studying the influence of age as a categorical variable $\left(F_{2,63}=2.744, p=.072\right)$. However, the subsequent study of the impact of age as a quantitative variable revealed a statistically significant and negative correlation $\left(\mathrm{r}_{\mathrm{xy}}=-.305\right)$.

Different studies, such as those of Bartoli et al. (2013) and Delavarian et al. (2015) pointed out that people with ASD made very frequent use of videogames, an observation corroborated in this investigation where it points out that $58.5 \%$ of people use videogames on a daily basis.

In relation to the platforms in use, the results of this study were in line with those found by Noor et al. (2012), highlighting the use of computers and the console as the most widely used resources by people with autism.

Connolly et al. (2012) concluded that entertainment was the main reason why people with ASD used videogames, an observation that was corroborated by the preference that $92 \%$ of the sample participating in this study expressed.

Grossard et al. (2017), in their systematic review of the use of videogames by people with ASD, pointed out that many different skills were applied in pursuit of entertainment that favored interactions in different contexts and situations, although they are not free from limitations. The results of this study are along the same lines, which highlight the development of mental activity, as a positive effect linked to videogames.

On the basis of the information gathered in this study and the views of people with ASD, videogames, as is evident from numerous studies, can have a positive effect 
on such aspects as intelligence and reflexes (Stone et al., 2018; Özge, 2017; Mazurek and Engelhardt, 2013; Cano et al., 2015; Mazurek et al., 2015).

Centering on the negative effects of the use of video games among people with ASD, studies such as the one developed by Grossard et al. (2017), highlighted the risk of reinforcing obsessions and repetitive behavior, a conclusion that is also reiterated in the results of this study when it shows that people with ASD express this aspect as the first negative consequence. Other studies go deeper into the analysis of the negative consequences for health, which the use of videogames produces in people with ASD. Engelhardt et al. (2013) have demonstrated that the emissions of light from mobile and computer screens can influence the sleeping-waking cycle, especially if they are used just before going to bed. This is an important factor to take into account, as some people with ASD already present sleeping difficulties arising from their disorder, which can be aggravated by the use of technology (Martínez and Cuesta, 2012).

In relation with health, as Evans (2014), Golden (2015), Golden and Getchell (2017) and Özen, 2015 pointed out, excessive use of the computer and the video-console can be associated with an excessively sedentary and overweight lifestyle. Likewise, a low muscular tone can in some cases lead to the adoption of slightly strange postures, which can also occur when in front of the television or other devices and can lead to muscular problems. Along these lines, Valencia-Peris (2013) and Díaz and Castañeda (2016) related sedentary lifestyles associated with the use of technologies with child obesity. Moreover, these authors agree with one of the results of this study, which highlights relaxation and the opportunity to evade problems as one of the advantages of the use of videogames. In this sense, the so-called active videogames that depend on the bodily movement of users, such as the WII or the Kinect games on XBOX, offer users with ASD an opportunity to conduct physical exercise, as they have an extra motivation, taking into account that physical wellbeing is one of the main dimensions that this group of people must be encouraged to develop (Cuesta et al., 2007).

Many people with ASD feel overwhelmed in the face of situations of excessive stimulation or very complex social situations and need to withdraw for a time to reduce their levels of stress. In this sense, videogames can help them in certain situations to focus their attention and will distract them from other stimuli that, given their hypersensitivity, can be more worrying (for example, facing a long wait, a place with many people and too much noise) (Villani et al., 2018). A high percentage of participants affirmed that they used videogames to relax, both in this study and in the one by Mazurek et al. (2015).

Some videogames, such as those of strategy and role-playing, which imply having a certain planning capability, a global vision of the situation, and cooperation (if it is an on-line game), can be good training in view of the difficulties that people with ASD present, related with weaknesses with executive functioning and central coherence. In this respect, a detailed study of such aspects would be of interest (Martínez and Cuesta, 2012).

The majority of the survey participants considered that videogames can, to a greater or lesser extent, be obsessive and create a degree of addiction, as Mazurek and 
Wenstrup affirmed (2013). In this sense, it would be of interest to reflect on whether videogames for people with ASD could in some cases enter among their restricted and/or repetitive interests, in such a way that it would not be possible to speak of obsession, but of a somewhat inflexible cognitive pattern. In these cases, videogames would be a center of specific interest, as well as a leisure activity, and they might possibly be interested in such topics as the authors, the technical sections, the graphic design, the avatars, etc.

Mazurek and Engelhardt (2013), in relation with the preference that many people with ASD expressed towards videogames, considered it effective to exploit their centres of interest, both on an educational plane where technology is a powerful ally, and on a social and labour-related plane, managing to turn their interests into employment opportunities. The field of video-games should be no exception in that respect.

It is worth highlighting that, although the very nature of videogames appeals to individual players, there are increasingly more games of a social nature that permit multi-players to play on-line in real time and a range of titles that offer cooperative games and on-line communities of players of the same game, which also increases the opportunities for socialization (Cuesta and Abella, 2012; Tsikinas and Xinogalos, 2019). The positions adopted towards this question hardly appear very conclusive, although a certain tendency may be appreciated to consider that digital leisure can allow players to socialize with people and make friendships. In this sense, it would be of interest to point out that videogames are widely entrenched in society in general and in increasingly more age segments as a leisure component. Hence, they represent an opportunity for people with ASD, who are also users and who in general like these games, to enter into conversation and exchange opinions around a different topic. Some people with ASD, as referenced in Chung et al. (2015), have a certain tendency to be persistent with their specific topics of interest that are often not shared by other people, which can provoke a certain degree of rejection. The case can also arise that people with ASD have no topic of conversation or that it is very difficult for them to start a conversation.

Therefore, meeting points for large numbers of users in videogame circles can offer satisfactory opportunities for social exchange. Neither may we dismiss out of hand the option that many games offer people a means of interaction over the Internet, as today the great majority of games offer the possibility of playing on-line, and chatting between players, as well specific forums on videogames, webpages, etc. These types of contacts and personal relations, although over a distance, are positive for many people with ASD, as they live with few social conventions, and both a non-verbal language and direct interactions, among others, are very simple for them to understand (Malinverni et al., 2010).

\section{Conclusions}

The relation between Information and Communications Technology (ICT) and Autism Spectrum Disorders (ASD) has been very close ever since the mass use of 
computers began in educational, domestic and occupational areas. Over recent years, there has been an exponential increase in the number of talks, investigations, courses, webpages, etc., exclusively dedicated to the use of new technologies and their use among the population with ASD in different fields: educational, behavioral, cognitive, social, and occupational, among others. The revolution that Internet has implied and mobile devices such as smart-phones and tablets, have meant that these technologies are definitively a powerful tool for work with people with autism.

However, digital leisure (videogames) understood as entertainment or leisure has not had the same volume of investigation or analysis, despite which, as happens with the rest of the population, people with ASD with solid cognitive functions are frequently users of this type of leisure, which has also shown itself to be highly entertaining for them.

This work is of an exploratory nature that explores the reality of life for people with ASD, so no generalized affirmations can be drawn from the conclusions that refer to the whole collective of people with ASD, but they are along the lines of other studies, in so far as they show that the majority of people with ASD who participated in this study liked videogames and played almost every day between one and three hours. Their main reasons were to play for pure entertainment or amusement, the improvement of certain capabilities, and the reduction of stress.

The way of playing is clearly individual, even though it was noted that the videogames, in so far as they are a sort of very extensive leisure form in society, can imply a good opportunity to promote communicative and social exchange between people with ASD.

The perceptions of players with ASD towards videogames is generally positive and only the idea that they can cause addiction or become obsessive appears to concern them, as opposed to other topics where the opinions are more varied, such as violence, physical pain, the time that they take away from other activities, and the isolation that accompanies their use.

On the theme and the type of videogame that people with ASD usually prefer, there appears to be no common profile among those surveyed, unless it depends on the tastes and the interests of each individual. Some people with ASD chose games related with topics of interest, others looked more closely at the technical or artistic part of the game, others looked for games that implied a challenge, and some simply played the videogames in accordance with their age or what was in fashion.

This work is nothing other than an approach to a topic that has been shown to be very broad and with multiple facets to take into account. It calls for more rigorous investigations, especially in relation to such topics as the possible benefits and problems associated with the videogames, opportunities for socialization, reduction of stress, therapeutic use and for the improvement of certain capabilities.

As the study was considered an initial approach to the topic, it included no sociodemographic variables. Future works might generate more specific investigations whenever relations between these sorts of data may be included.

An important future challenge for videogames is greater accessibility options for the population with ASD. Developers need to be aware that software of this type 


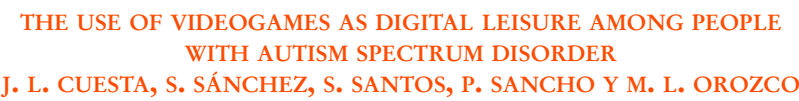

and its information can be processed in different ways for people especially sensitive towards certain stimulants and other peculiarities that should not be considered a barrier when accessing digital leisure.

\section{Bibliographical references}

Acedo, M. T., Herrera, S. S. and Traver, M. T. B. (2016). Las Tic como herramienta de apoyo para personas con Trastorno del Espectro Autista (TEA). Revista de Educación Inclusiva, 9(2), 102-136.

Ang, S. S., Orozco, M., Gijbels, D. and Van den Bossche, P. (2018). Learning in the context of work in a digital age: the use of digital media in informal and formal learning contexts. In C. Harteis (Ed.), The impact of digitalization in the workplace. Professional and practicebased learning, vol. 21. Springer, Cham. https://doi.org/10.1007/978-3-319-63257-5_7

Apa. American Psychiatric Association. (2013). Diagnostic and Statistical Manual of Mental Disorders (Dsm-5®). American Psychiatric Association.

Asociación Española De Distribuidores Y Editores De Software De Entretenimiento (aDese). (2011). El videojugador español: perfil, hábitos e inquietudes de nuestros gamers. https://www.aevi.org.es/el-videojugador-espanol-perfil-habitos-e-inquietudes-de-nuestros-gamers/

Baldassarri, S., Passerino, L., Ramis, S., Riquelme, I. and Perales, F. J. (2020). Toward emotional interactive videogames for children with autism spectrum disorder. Universal Access in the Information Society, June, 1-16. https://doi.org/10.1007/s10209-020-00725-8

Bartoli, L., Corradi, C., Garzotto, F. and Valoriani, M. (2013). Exploring motionbased touchless games for autistic children's learning. In Proceedings of the 12th International Conference on Interaction Design and Children (pp. 102-111). https://doi. org $/ 10.1145 / 2485760.2485774$

Blythe, A., Corbett, B., Blain, S. and Edmiston, E. (2018). The role of context in psychosocial stress among adolescents with autism spectrum disorder: piloting a semi-structured, videogame-based paradigm. Journal of Intellectual and Developmental Disability, 43(1) 120-128. http//dx.doi.org/10.1044/2017_AJSLP-17-0073

Cano, A. R, García Á. J. and Fernández, B. (2015). Destacados en la literatura disponible en juegos serios para discapacidades intelectuales. In F. Li, R. Klamma, M. Laanpere, J. Zhang, B. MANjón and R. LAU (Eds.), Advances in web-based learning - ICwl 2015. ICWL 2015. Lecture Notes in Computer Science, vol. 9412. Springer, Cham. https://doi. org/10.1007/978-3-319-25515-6_9

Chan, J., Lambdin, L., Van Laarhoven, T. and Johnson, J. (2013). Teaching leisure skills to an adult with developmental disabilities using a video prompting intervention package. Education and Training in Autism and Developmental Disabilities, 48(3), 412-420.

Chung, P., Vanderbilt, D. and Soares, N. (2015). Social behaviors and active videogame play in children with Autism Spectrum Disorder. Games for Health Journal, 4(3), 225-234. https://doi.org/10.1089/g4h.2014.0125

Cintado, J. L., Bueno, C. M., Rodríguez, M. B., Bueno, E. M., Martínez, M. L. De La F., and Muñoz, L. G. (2016). Una “inclusiva” mirada de la tecnología en nuestro colegio. Trabajando con una mirada especial: TeA y Tic en nuestro colegio. Padres y maestros. Publica- 


\section{THE USE OF VIDEOGAMES AS DIGITAL LEISURE AMONG PEOPLE WITH AUTISM SPECTRUM DISORDER \\ J. L. CUESTA, S. SÁNCHEZ, S. SANTOS, P. SANCHO Y M. L. OROZCO}

ción de la Facultad de Ciencias Humanas y Sociales, 365, 41-48. https://doi.org/10.14422/ pym.i365.y2016.006

CoHEn, J. (1988). Statistical power analysis for the behavioral sciences. Routledge Academic.

Connolly, T. M., Boyle, E. A., Macarthur, E., Hainey, T. and Boyle, J. M. (2012). A systematic literature review of empirical evidence on computer games and serious games. Computers and Education, 59(2), 661-686.

Cuesta, J. L. and Abella, V. (2012). Tecnologías de la información y la comunicación: aplicaciones en el ámbito de los Trastornos del Espectro del Autismo. Siglo Cero, 43(2), 6-25.

Cuesta, J. L., De la Fuente, R., Vidriales, R., Fernández, C., Plaza, M. and González, J. (2017). Bienestar físico, dimensión clave de la calidad de vida en las personas con autismo. International Journal of Developmental and Educational Psychology, 1(3), 33-44. https:// doi.org/10.17060/ijodaep.2017.n1.v4.1025

Delavarian, M., Bokharaeian, B., Towhidkhah, F. and Gharibzadeh, S. (2015). Computerbased working memory training in children with mild intellectual disability. Early Child Development and Care, 185(1), 66-74.

Díaz, R. and Aladro, M. (2016). Relación entre uso de las nuevas tecnologías y sobrepeso infantil, como problema de salud pública. RqR Enfermería Comunitaria (Revista de SEAPA), 4(1), 46-51.

DuRkin, K. (2010). Videogames and young people with developmental disorders. Review of General Psychology, 14(2), 122-140. https://doi.org/10.1037/a0019438

EDward, U. (2016). Digital leisure, the internet and popular culture: communities and identities in a digital age, by Karl Spracklen. Leisure/Loisir, 40(2), 245-246. https://doi.org/10.1 080/14927713.2016.1220747

Engelhardt, C. R., Mazurek, M. O. and Sohl, K. (2013). Media use and sleep among boys with autism spectrum disorder, ADHD, or typical development. Pediatrics, 132(6), 10811089. https://doi.org/10.1542/peds.2013-2066

EsPinO, M. G. (2010). El blog como herramienta de expresión para un alumno con trastorno del espectro autista. Campo Abierto. Revista de Educación, 29(1), 147-163.

Evans, J. P. (2014). Physical activity level comparisons of individuals with autism spectrum disorder while playing active video games (Doctoral dissertation). Institutional repository University of Wisconsin. http://digital.library.wisc.edu/1793/70139

Finke, E., Hickerson, B. and Kremkow, J. (2018). “To be quite honest, if it wasn't for videogames i wouldn't have a social life at all": motivations of young adults with Autism Spectrum Disorder for playing videogames as leisure. American Journal of Speech-Language Patho$\log y, 27(2), 672-689$. https://doi.org/10.1044/2017_AJSLP-17-0073

FletCher-WATSON, S. (2015). Evidence-based technology design and commercialisation: recommendations derived from research in education and autism. TechTrends, 59(1), 84-88. https://doi.org/10.1007/s11528-014-0825-7

Frith, U. (1989). Autism: explaining the enigma. Wiley Online Library.

Golden, D. (2015). The short-term effect of Xbox Kinect active videogame on physical activity levels and executive function in children with and without autism spectrum disorder (Doctoral dissertation). Institutional repository University of Delaware. http://udspace.udel. edu/handle/19716/17569

Golden, D. and Getchell, N. (2017). Physical activity levels in children with and without Autism Spectrum Disorder when playing active and Sedentary Xbox Kinect Videogames. Games for Health Journal, 6(2), 97-103. https://doi.org/10.1089/g4h.2016.00833 
Grossard, C., Grynspan, O., Serret, S., Jouen, A. L., Bailly, K. and Cohen, D. (2017). Serious games to teach social interactions and emotions to individuals with Autism Spectrum Disorders (ASD). Computers and Education, 113, 195-211.

Grzadzinski, R., Huerta, M. and Lord, C. (2013). Dsm-5 and autism spectrum disorders (AsDs): an opportunity for identifying AsD subtypes. Molecular Autism, 4(1), 12. https:// doi.org/10.1186/2040-2392-4-12

Happé, F. (2011). Criteria, categories, and continua: autism and related disorders in Dsm-5. Journal of the American Academy of Child and Adolescent Psychiatry, 50(6), 540-542. https://doi.org/10.1016/j.jaac.2011.03.015

Harn, Y. (2018). Putting a face to the game: the intellectual property implications of using celebrity likenesses in videogames. Journal of Intellectual Property Law and Practice, 13(2), 143-153. https://doi.org/10.1093/jiplp/jpx193

Jiménez, J. R., (2011). Perspectivas en educación mediada por Tic para el contexto autista. Revista de Educación Inclusiva, 4(2), 113-122.

Kientz, J., Goodwin, M., Hayes, G. and Abowd, G. (2013). Interactive technologies for autism. Synthesis Lectures on Assistive, Rehabilitative, and Health-Preserving Technologies, 2(2), 1-177. https://doi.org/10.2200/S00533ED1v01Y201309ARH004

Lozano, J., Ballesta, F. J. and Alcaraz, S. (2011). Software for teaching emotions to students with Autism Spectrum Disorder. Comunicar, 18(36), 139-148. https://doi.org/10.3916/ C36-2011-03-05

Malinverni, L., Mora-Guiard, J., Padillo, V., Valero, L., Hervás, A. and Pares, N. (2017). An inclusive design approach for developing video games for children with Autism Spectrum Disorder. Computers in Human Behavior, 71, 535-549. https://doi.org/10.1016/j. chb.2016.01.018

Martínez, M. A. and Cuesta, J. L. (2012). Todo sobre el autismo: los Trastornos del Espectro del Autismo (Tea). Guía completa basada en la ciencia y en la experiencia. Altaria.

Martínez, J. L., Pagán, F. J., García, S. A. and Máiquez, M. C. (2016). Las tecnologías de la información y comunicación (TIC) en el proceso de enseñanza y aprendizaje del alumnado con trastorno del espectro autista (TEA). Revista Fuentes, O(14), 193-208.

Mazurek, M. O. and Engelhardt, C. R. (2013). Video game use and problem behaviors in boys with autism spectrum disorders. Research in Autism Spectrum Disorders, 7(2), 316324. https://doi.org/10.1016/j.rasd.2012.09.008

Mazurek, M. O., Engelhardt, C. R. and Clark, K. E. (2015). Video games from the perspective of adults with autism spectrum disorder. Computers in Human Behavior, 51, 122-130. https://doi.org/10.1016/j.chb.2015.04.062

Mazurek, M. O. and Wenstrup, C. (2013). Television, video game and social media use among children with ASD and typically developing siblings. Journal of Autism and Developmental Disorders, 43(6), 1258-1271. https://doi.org/10.1007/s10803-012-1659-9

Montero, M. G. (2012) Uso de dispositivos táctiles en Educación Especial. In C. Alonso, C. and D. Gallego. CD de actas del XVII Congreso Internacional de Tecnologías Emergentes de la UNED. Electronic Version. Anaya.

Nieto, C., Murillo, E., Belinchón, M., Giménez, A., Saldana, D., Martínez, M. A. and Frontera, M. (2015). Supporting people with autism spectrum disorders in leisure time: impact of a University Volunteer Program and related factors. Journal of Psychology, 31(1), 145-154. https://doi.org/10.6018/analesps

Noor, H. A. M., Shahbodin, F. and Pee, N. C. (2012). Serious game for autism children: review of literature. World Academy of Science, Engineering and Technology. International 
THE USE OF VIDEOGAMES AS DIGITAL LEISURE AMONG PEOPLE

WITH AUTISM SPECTRUM DISORDER

J. L. CUESTA, S. SÁNCHEZ, S. SANTOS, P. SANCHO Y M. L. OROZCO

Journal of Social, Behavioral, Educational, Economic, Business and Industrial Engineering, 6(4), 554-559.

Orozco, G. H., Tejedor, F. J. and Calvo, M. I. (2017). Meta-analysis in the efect of educative software on students with special educational needs. Journal of Educational Research, 35(1), 35-52. https://doi.org/10.6018/rie.35.1.240351

ÖZEN, A. (2015). Effectiveness of siblings-delivered ipad game activities in teaching social interaction skills to children with Autism. Spectrum Disorders. Educational Sciences: Theory and Practice, 15(5), 1287-1303. https://doi.org/10.12738/estp.2015.5.2830

ÖZge, A. (2017). Determining studies conducted upon individuals with Autism Spectrum Disorder using high-tech devices. Educational Sciences: Theory and Practice, 17(1), 27-45. https://doi.org/10.12738/estp.2017.1.0236

SHIC, F. and Goodwin, M. (2015). Introduction to technologies in the daily lives of individuals with Autism. Journal of Autism and Developmental Disorders, 45(12), 3773-3776. https:// doi.org/10.1007/s10803-015-2640-1

Spracklen, K. (2015). Digital leisure, the internet and popular culture: Communities and identities in a digital age. Palgrave Macmillan. https://doi.org/10.1057/9781137405876

Stone, B., Mills, K. and Saggers, B. (2018). Online multiplayer games for the social interactions of children with autism spectrum disorder: a resource for inclusive education. Journal of Applied Science and Computations, 5(12), 2407-2410. https://doi.org/10.1080/13603116 .2018 .1426051

Torrente, F. J. (2015). Mejorando la accesibilidad de los serious games mediante herramientas de autoría (Doctoral dissertation). Institutional repository University Complutense of Madrid. https://eprints.ucm.es/28205/

Travers, B., Mason, A., Leigh, M., Ellerson, A. Deanll, D., Engel, C., Gómez, A., DaDalko, O. and Mclaughlin, K. (2018). Biofeedback-based, videogame balance training in Autism. Journal of Autism and Developmental Disorders, 48(1), 163-175. https://doi. org/10.1007/s10803-017-3310-2

Tsikinas, S., and Xinogalos, S. (2019). Studying the effects of computer serious games on people with intellectual disabilities or autism spectrum disorder: a systematic literature review. Journal of Computer Assisted Learning, 35, 61-73. https://doi.org/10.1111/jcal.12311

Valencia-Peris, A. (2013) Actividad física y uso sedentario de medios tecnológicos de pantalla en adolescentes (Doctoral dissertation). Institutional repository University of Valencia. http://hdl.handle.net/10550/28151

Villani, D., Carissoli, C., Triberti, S., Marchetti, A., Gilli, G. and Riva, G. (2018). Videogames for emotion regulation: a systematic review. Games for Health Journal, 7(2), 85-99. https://doi.org/10.1089/g4h.2017.0108

Yaghoubi, H., Karimlo, M. and Hajdivanbachari, S. (2019). Video games on the behavior of children with Autism Spectrum Disorder. Eastern Journal of Disability Studies, 9, 64. 


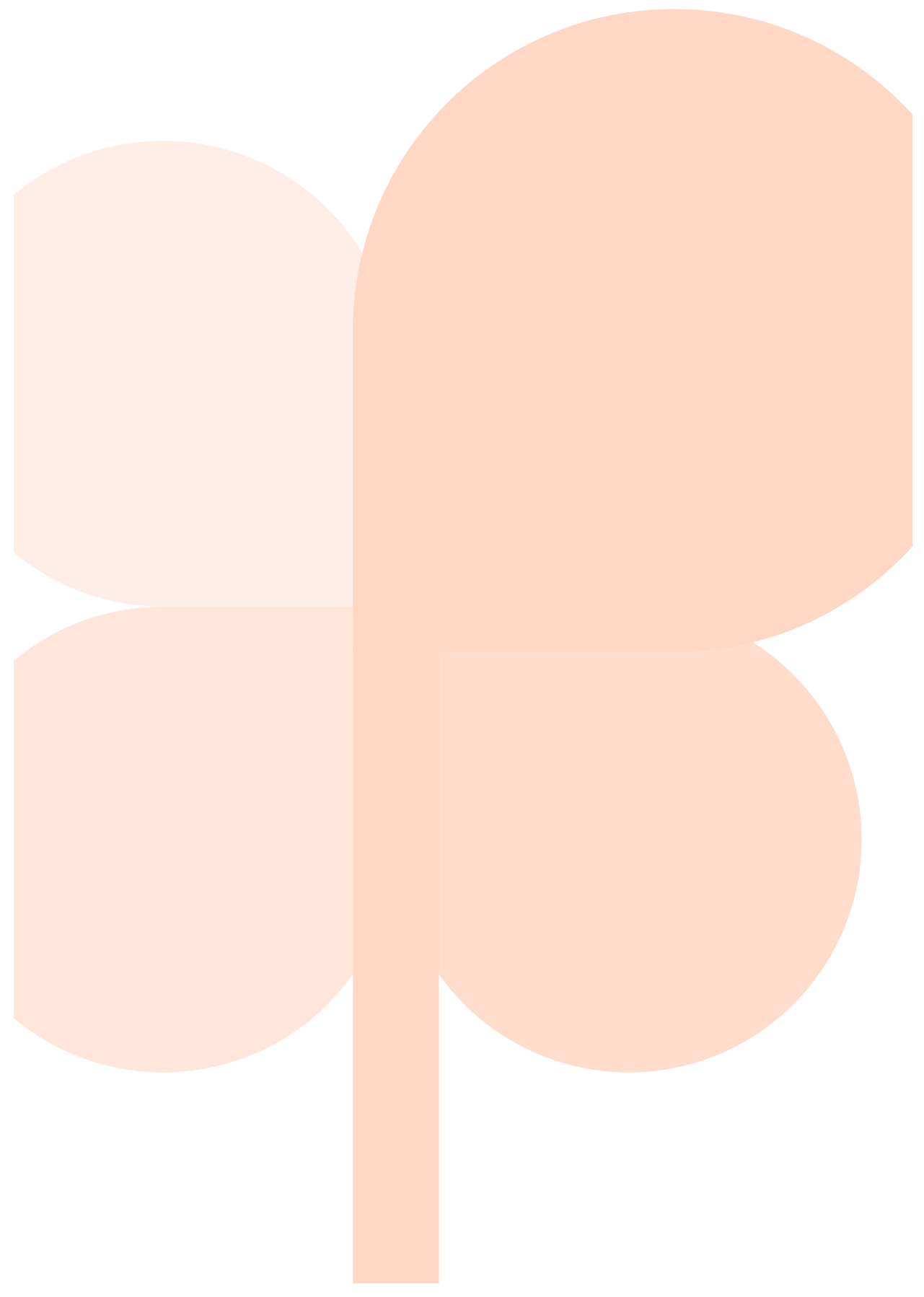

